(c) American Dairy Science Association, 2005.

\title{
Antimicrobial Susceptibility and Coagulase Gene Typing of Staphylococcus aureus Isolated from Bovine Clinical Mastitis Cases in Turkey
}

\author{
L. Güler, ${ }^{1}$ Ü. OK, ${ }^{1}$ K. Gündüz, ${ }^{1}$ Y. Gülcü, ${ }^{1}$ and H. H. Hadimli ${ }^{2}$ \\ ${ }^{1}$ Veterinary Control and Research Institute, Konya, Turkey \\ ${ }^{2}$ Selçuk University Veterinary Faculty, Department of Microbiology, Konya, Turkey
}

\begin{abstract}
The objectives of this study were to determine antimicrobial resistance patterns of Staphylococcus aureus strains isolated from bovine clinical mastitis cases and to subtype the strains by polymerase chain reaction (PCR) technique based on coagulase gene polymorphism. Two hundred sixty-five $S$. aureus isolates collected from individual animals in different herds $(\mathrm{n}=235)$ from 1995 to 2004 were tested for susceptibility to penicillin, ampicillin, amoxicillin-clavulanate, oxacillin, oxytetracycline, enrofloxacin, kanamycin-cephalexin, and trimethoprimsulfamethoxazole using the agar disc diffusion test. Strains were also tested for $\beta$-lactamase production. A total of $29.8 \%$ of the strains were susceptible to all antimicrobial agents tested. The highest resistance was observed in $63.3 \%$ of the strains against $\beta$-lactam antibiotics, penicillin and ampicillin. Oxytetracycline resistance was observed in $27.9 \%$ of the strains, either alone or in combination with $\beta$-lactams. No resistance was detected for amoxicillin-clavulanate, oxacillin, enrofloxacin and kanamycin-cephalexin. $\beta$-Lactamase production and resistance to $\beta$-lactam antibiotics were usually correlated. Resistance against $\beta$-lactams increased from $43.5 \%$ in 1995 to 58 to $77 \%$ from 1999 to 2004 .

One hundred twenty-five strains were examined for coagulase gene polymorphism. The isolates were subtyped into 4 types by coagulase gene-based PCR. A predominant 1000-bp PCR product was observed in $60.8 \%$ of the isolates typed. The results indicate that a few coagulase gene types of $S$. aureus are responsible for the majority of bovine clinical mastitis cases in one province of Central Anatolia region, Turkey.
\end{abstract}

(Key words: Staphylococcus aureus, antimicrobial susceptibility, coagulase-gene typing, bovine mastitis)

\section{INTRODUCTION}

Staphylococcus aureus is a major pathogen of bovine mastitis worldwide. Despite implementing intensive

Received February 17, 2005.

Accepted May 2, 2005.

Corresponding author: L. Güler; e-mail: gulerleyla@hotmail.com. control measures, it is difficult to eradicate the intramammary infections caused by this pathogen and it remains a substantial economic problem. Antimicrobial therapy is one of the measures for controlling staphylococcal mastitis. The cure rates for $S$. aureus mastitis are affected by several factors, including antimicrobial resistance of the isolates. The determination of antimicrobial susceptibility of clinical isolates is required not only for therapy but also for monitoring the spread of resistant strains throughout the populations. Although antimicrobial susceptibility testing is a valuable tool in determining the best therapeutic choice against a mastitis pathogen, in practice it is rarely performed and therapy decisions are usually made empirically. Therefore, susceptibility data for a large number of isolates in an area or region can be useful to veterinarians (Salmon, 2002).

It is known that phenotypically and genotypically different many strains of $S$. aureus exist; however, there is little information about distribution of the types of the pathogen in herds and geographic locations. Previously, several different phenotyping and genotyping techniques have been applied for subtyping of $S$. aureus isolates of both bovine and human origin, such as phage typing (Zadoks et al., 2002; Vintov et al., 2003), plasmid analysis (Aarestrup et al., 1995b; Lange et al., 1999), ribotyping (Myllys et al., 1997), pulse-field gel electrophoresis (Zadoks et al., 2002; Sabour et al., 2004), multilocus enzyme electrophoresis (Kapur et al., 1995), PCR-based fingerprinting (Lipman et al., 1996; Fitzgerald et al., 1997, 2000), amplification of specific gene regions (Annemüller et al., 1999; Lange et al., 1999), and binary typing (Zadoks et al., 2002). Unfortunately no single technique is yet available that is superior to the others (Tenover et al., 1994).

The coagulase protein is an important phenotypic determinant and accepted as a major virulence factor of $S$. aureus. Analysis of coagulase-encoding $S$. aureus DNA $(c o a)$ genes has demostrated variable sequences in the 3'-end coding region (Goh et al., 1992). This region contains a polymorphic repeat region that can be used to differentiate $S$. aureus isolates. This characteristic has 
been used to type $S$. aureus isolates of human and bovine origin (Schwarzkopf and Karch, 1994; Aarestrup et al., 1995a; Hookey et al., 1998; Annemüller et al., 1999; Lange et al., 1999; Raimundo et al., 1999; Su et al., 1999; Schlegelova et al., 2003).

Recently, many studies have been carried out on molecular epidemiology and antimicrobial resistance patterns of bovine $S$. aureus isolates mainly from Europe and the United States; however there are limited data from Turkey. The aim of this study was to investigate antimicrobial resistance patterns and epidemiological relatedness using coagulase gene typing among $S$. aureus strains isolated from bovine clinical mastitis cases from 1995 to 2004 in one province of Central Anatolia.

\section{MATERIALS AND METHODS}

\section{Bacterial Strains}

A total of $265 S$. aureus strains isolated from milk samples submitted to Konya Veterinary Control and Research Institute diagnostic laboratory from 1995 to 2004 were examined. The strains were obtained from individual cows with clinical mastitis from different herds $(\mathrm{n}=$ 235) located in Konya province in Central Anatolia. Each of 233 isolates was obtained from different herds; only 32 isolates were from 2 herds, with 27 and 5 isolates from year 2000 and 2003, respectively.

Primary culture of milk samples was performed on sheep blood agar plates. Isolates were identified using standard microbiological techniques (Quinn et al., 1998) and were stored at $-70^{\circ} \mathrm{C}$ in trypticase soy broth containing $15 \%$ glycerol. Coagulase test was performed using the staphylase test kit (Oxoid Limited, Hampshire, UK).

\section{$\beta$-Lactamase Production}

All $S$. aureus isolates were tested for $\beta$-lactamase production using the chromogenic cephalosporin method ( $\beta$ lactamase sticks; Oxoid Limited) according to the manufacturer's instructions.

\section{Antimicrobial Susceptibility Testing}

Antimicrobial susceptibility test was performed on Mueller Hinton agar by disk diffusion method (NCCLS Standards, 2002) using the following antimicrobial agents: penicillin (10 IU), ampicillin $(10 \mu \mathrm{g})$, amoxicillinclavulanate $(20 \mu \mathrm{g} / 10 \mu \mathrm{g})$, oxytetracycline $(30 \mu \mathrm{g})$, enrofloxacin $(5 \mu \mathrm{g})$, kanamycin-cephalexin $(30 \mu \mathrm{g} / 45 \mu \mathrm{g})$, trimethoprim-sulfamethoxazole $(1.25 \mu \mathrm{g} / 23.75 \mu \mathrm{g})$ and oxacillin $(1 \mu \mathrm{g})$. Reference strain $S$. aureus ATCC 25923 was used as the quality control organism and included with each batch of isolates tested. For kanamycin-cephalexin, no NCCLS criteria are available; $\geq 20 \mathrm{~mm}$ was evaluated as susceptible. Inhibition zone of ATCC 25923 for kanamycin-cephalexin combination was $29 \mathrm{~mm}$ and for oxytetracycline was within the range of the class representative, tetracycline.

\section{Coagulase Gene Typing}

DNA extraction for PCR analysis. Staphylococcus aureus DNA was extracted from overnight cultures in $10 \mathrm{~mL}$ of brain heart infusion broth with slight modifications of the method reported by Hesselbarth and Schwarz, 1995. Briefly, bacterial cells were collected by centrifugation for $30 \mathrm{~s}$ at $14,000 \mathrm{rpm}$, washed in $1 \mathrm{~mL}$ of TES buffer ( $10 \mathrm{~m} M$ Tris $\cdot \mathrm{HCl}, \mathrm{pH} 8.0 ; 1 \mathrm{~m} M$ EDTA; $100 \mathrm{~m} M \mathrm{NaCl}$ ), and recentrifuged. The pellet was resuspended in $500 \mu \mathrm{L}$ of TES buffer including $2 \mu \mathrm{L}$ of lysostaphin (stock concentration $2 \mu \mathrm{g} / \mathrm{mL}$; Sigma-Aldrich, St. Louis, MO) and $12.5 \mu \mathrm{g}$ of lysozyme (AppliChem, Darmstadt, Germany) and incubated for $30 \mathrm{~min}$ at $37^{\circ} \mathrm{C}$. Lysis was completed by the addition of $20 \mu \mathrm{L}$ of $10 \%$ SDS solution and incubation for $15 \mathrm{~min}$ at room temperature. DNA was then extracted with phenol-chloroform-isoamylalchohol 25:24:1 and chloroform-isoamylalchohol 24:1, respectively. The DNA was precipitated from the supernatant with an equal volume of isopropanol at $-80^{\circ} \mathrm{C}$ for at least $1 \mathrm{~h}$. After final centrifugation, the supernatant was discarded, the pellet was dried and resuspended in $50 \mu \mathrm{L}$ of ultrapure water.

PCR analysis. Polymerase chain reaction analysis of the coa gene was carried out using the primers COAG2 (5' CGAGACCAAGATTCAACAAG 3') and COAG3 (5' AAAGAAAACCACTCACATCA $3^{\prime}$ ) described by Goh et al. (1992). Reaction was performed in a final volume of $50 \mu \mathrm{L}$ of mixture containing PCR buffer (10 mM Tris $\cdot \mathrm{HCl}, \mathrm{pH} 9.0 ; 50 \mathrm{mM} \mathrm{KCl}$, and $0.1 \%$ Triton X-100), $1.5 \mathrm{mM} \mathrm{MgCl} 2,250 \mu M$ each of the deoxynucleoside triphosphates, $0.5 \mu M$ each of the coa gene-specific primers, 1.25 U of Taq DNA polymerase (Promega, Madison, WI) and $5 \mu \mathrm{L}$ of template. The amplification program included an initial denaturation step of 2 min at $94^{\circ} \mathrm{C}$ followed by 30 cycles of $30 \mathrm{~s}$ at $94^{\circ} \mathrm{C}, 2 \mathrm{~min}$ at $55^{\circ} \mathrm{C}$ and $4 \mathrm{~min}$ at $72^{\circ} \mathrm{C}$, and a final extension step of $7 \mathrm{~min}$ at $72^{\circ} \mathrm{C}$ (Lange et al., 1999). The products of $7 \mu \mathrm{L}$ were analyzed by electrophoresis through a $1.5 \%$ agarose gel after which the gel was stained with ethidium bromide and photographed.

Restriction endonuclease digestion. Seven microliters of PCR product was incubated with $10 \mathrm{U}$ of AluI (Fermentas Int., Inc., Vilnius, Lithuania) at $37^{\circ} \mathrm{C}$ for $2 \mathrm{~h}$. Ten microliters of the digested PCR product was electrophoresed in $1.5 \%$ agarose gel, stained with ethidium bromide, and visualized under UV light. 
Table 1. Antimicrobial resistance of 265 Staphylococcus aureus strains isolated from bovine clinical mastitis cases.

\begin{tabular}{lcc}
\hline & \multicolumn{2}{c}{ Resistant isolates } \\
\cline { 2 - 3 } Antimicrobials & Number & $\%$ \\
\hline Penicillin & 168 & 63.3 \\
Ampicillin & 168 & 63.3 \\
Oxytetracycline & 74 & 27.9 \\
Trimethoprim-sulfamethoxazole & 5 & 1.8 \\
Amoxicillin-clavulanate & 0 & 0 \\
Oxacillin & 0 & 0 \\
Enrofloxacin & 0 & 0 \\
Kanamycin-cephalexin & 0 & 0 \\
\hline
\end{tabular}

\section{RESULTS}

All of the isolates were coagulase-test positive and showed $\alpha$ and $\beta$-hemolysis in sheep blood agar and identified as $S$. aureus.

\section{Antimicrobial Susceptibility}

Antimicrobial susceptibility test results of $265 \mathrm{~S}$. aureus strains are shown in Tables 1 and 2. A total of $79(29.8 \%) S$. aureus isolates were susceptible to all antimicrobial agents tested. One hundred sixty-eight (63.3\%) of the strains were resistant to penicillin and ampicillin. A total of $74(27.9 \%)$ strains were resistant to oxytetracycline, 18 (6.7\%) of them alone, $56(21.1 \%)$ of them together with $\beta$-lactams, and $33.3 \%$ of penicillinresistant strains were resistant to oxytetracycline. Only $5(1.8 \%)$ strains were resistant to trimethoprim-sulfamethoxazole. No resistance was detected for oxacillin, amoxicillin-clavulanate, enrofloxacin, or kanamycincephalexin. Distribution of penicillin-resistant strains according to years is shown in Table 3. Among the 27 $S$. aureus isolates belonging to one herd, 10 strains were sensitive to all antimicrobials tested, 10 strains were resistant to penicillin, ampicillin plus oxytetracycline, 5 strains were resistant to only oxytetracycline, and 2 strains were resistant to penicillin and ampicillin. However, 5 strains belonging to the other herd showed a

Table 2. Antimicrobial resistance patterns of 265 Staphylococcus aureus isolates.

\begin{tabular}{llrr}
\hline & & \multicolumn{2}{c}{ Resistant isolates } \\
\cline { 3 - 4 } Pattern & profile $^{1}$ & Number & $\%$ \\
\hline 1 & Pen. Amp & 109 & 41.1 \\
2 & Pen. Amp, Oxy & 54 & 20.3 \\
3 & Oxy & 18 & 6.7 \\
4 & Pen, Amp, Sxt & 3 & 1.1 \\
5 & Pen, Amp, Oxy, Sxt & 2 & 0.7 \\
6 & All susceptible & 79 & 29.8 \\
\hline
\end{tabular}

${ }^{1}$ Pen $=$ Penicillin, Amp = ampicillin, Oxy $=$ oxytetracycline, Sxt $=$ trimethoprim-sulfamethoxazole.
Table 3. Penicillin resistance among 265 Staphylococcus aureus strains isolated from bovine clinical mastitis cases from 1995 to 2004.

\begin{tabular}{lccc}
\hline & \multirow{2}{*}{$\begin{array}{l}\text { Number } \\
\text { of isolates } \\
\text { tested }\end{array}$} & \multicolumn{2}{c}{$\begin{array}{c}\text { Penicillin-resistant } \\
\text { isolates }\end{array}$} \\
\cline { 3 - 4 } Years & 39 & No. & $\%$ \\
\hline 1995 & 24 & 17 & $43.5 \%$ \\
1999 & 55 & 17 & $70.8 \%$ \\
2000 & 37 & 32 & $58.1 \%$ \\
2001 & 42 & 25 & $67.5 \%$ \\
2002 & 42 & 28 & $66.6 \%$ \\
2003 & 26 & 29 & $69.0 \%$ \\
2004 & 265 & 20 & $76.9 \%$ \\
Total & & 168 & \\
\hline
\end{tabular}

similar pattern of resistance, all were resistant to penicillin and ampicillin plus oxytetracycline.

A total of $152(57.3 \%)$ strains were positive for $\beta$-lactamase test. Only $16 \beta$-lactam antibiotics resistant strains were $\beta$-lactamase negative.

\section{Coagulase Gene Typing}

The PCR amplification of coagulase gene of $125 \mathrm{~S}$. aureus isolates distinguished $4 \mathrm{PCR}$ products of approximately 1000, 900, 800, and $700 \mathrm{bp}$ (Figure 1). The 1000bp PCR product was observed in $76(60.8 \%)$ isolates whereas the 900-, 800-, and 700-bp products were found in $21(16.8 \%), 16(12.8 \%)$, and $12(9.6 \%)$, respectively. Among the $27 \mathrm{~S}$. aureus strains from one herd, 12 were tested by coa-PCR; in 10 strains, $1000-b p$ (83.3\%), in 1 strain, 700-bp, and in 1 strain, 800-bp products were identified.

Only 20 S. aureus strains with $1000-b p$ PCR products were digested by $A l u \mathrm{I}$ restriction enzyme. Two different patterns of fragments were detected after $A l u \mathrm{I}$ digestion,

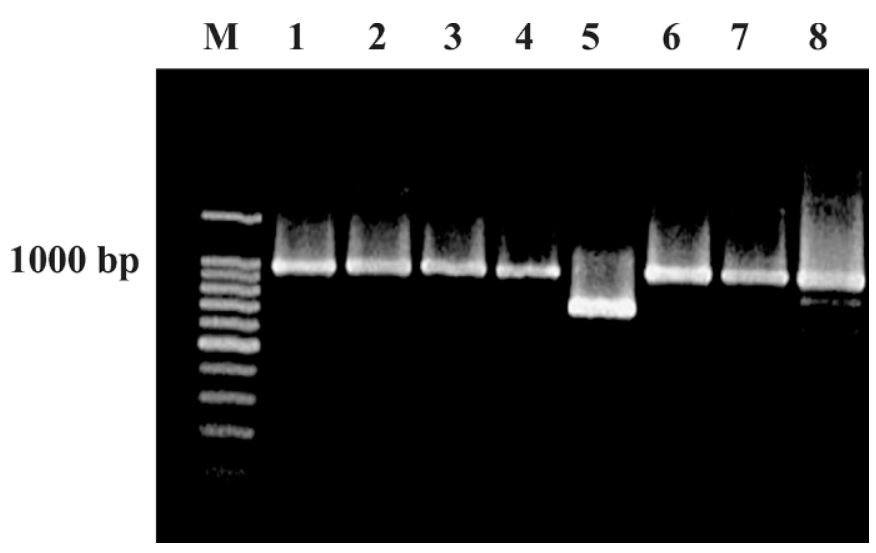

Figure 1. Presentation of coagulase gene PCR products of Staphylococcus aureus isolates. M: 100-bp marker (Promega, Madison, WI); lanes 1 to 4; lanes 6 to 8: 1000-bp products; lane 5: 700-bp product. One single strong band was produced with each strain. 
14 strains yielded the pattern of approximately 500,320 , and $180 \mathrm{bp}$, and in 6 strains the pattern was approximately 400, 260, and $80 \mathrm{bp}$.

\section{DISCUSSION}

$\beta$-Lactam antibiotics are among the most widely used antimicrobial agents for the treatment of bovine mastitis. Many studies from different countries have showed that among $S$. aureus strains isolated from bovine mastitis cases, the highest resistance was observed against penicillin, a $\beta$-lactam antibiotic, and resistance to other antimicrobials was usually low (Aarestrup et al., 1995b; Erskine et al., 2002, 2004; Vintov et al., 2003; Sabour et al., 2004). In accordance with previous studies, resistance frequency in the present study was highest (63.3\%) against the $\beta$-lactam antibiotics, penicillin and ampicillin. However, the frequency of penicillin resistance varies among countries. This may be linked to many factors, such as the differences in animal production systems and national policies for the use of antimicrobial drugs in each country. Vintov et al. (2003) found penicillin resistance with an average of $32.4 \%$ among $S$. aureus isolates from bovine mastitis in 9 European countries and the United States. Penicillin resistance was high among the isolates from Ireland (71.4\%), the United Kingdom (67.3\%), and the United States (50\%), whereas it was low among the isolates from the Scandinavian countries, with $2 \%$ in Norway. In an earlier study using the same isolates, De Oliveira et al. (2000) determined that the percentage of $\beta$-lactamase-producing strains is correlated with the percentage of penicillin resistance in these countries. In addition, they reported that the level of resistance for penicillin was low regardless of country, the $\mathrm{MIC}_{90}$ for penicillin were within 0.25 to 0.5 $\mu \mathrm{g} / \mathrm{mL}$ and $\leq 0.06 \mu \mathrm{g} / \mathrm{mL}$ in Norway (De Oliveira et al., 2000 ). In this study, following the $\beta$-lactam resistance, the second highest resistance occurred against oxytetracycline (27.9\%) among $S$. aureus strains. Similar results were found by other studies (Vecht et al., 1989; Leslie et al., 2003).

The findings of this study show that penicillin resistance is relatively higher in Turkey than that is in other countries (Aarestrup et al., 1995b; Gentilini et al., 2000; Calvinho et al., 2002; Gianneechini et al., 2002; Yoshimura et al., 2002; Pengov and Ceru, 2003). Studies carried out on bovine mastitis in different geographical regions of Turkey have also showed high frequency of penicillin resistance (Akan et al., 2001; Hadimli et al., 2001; Türütoğlu et al., 2002).

Some studies showed that frequency of penicillin resistance has increased over time. In a survey carried out in Finland (Myllys et al., 1998), it was reported that the proportion of $S$. aureus isolates resistant to at least one antibacterial agent increased from 36.9 to $63.6 \%$ from 1988 to 1995 , and most of the increase in antibacterial resistance was due to $\beta$-lactamase producing strains; in the 2000 survey (Pitkala et al., 2004), penicillin resistance for $S$. aureus was reported as $52.1 \%$. Similarly, in a Belgian study (Devriese et al., 1997), percentages of S. aureus strains producing penicillinase were reported that rapidly increased from $38 \%$ in 1971 to $70-80 \%$ throughout the next 2 decades and in 1996 the percentage of resistant strains was reported as $51 \%$. Some recent studies indicate a trend of decreasing resistance to penicillin in $S$. aureus isolates (Erskine et al., 2002; Macovec and Ruegg, 2003). It seems that after a rapid trend of increase, the percentage of resistant strains has not changed over time or slight decreases are observed. Likewise, the findings of this study represent that penicillin resistance increased from $43.5 \%$ in 1995 to $70.8 \%$ in 1999, and no noticeable changes were observed during the following years. Unfortunately, there were not any isolates from the years of 1996-98.

Resistance to $\beta$-lactam antibiotics is most often caused by the production of $\beta$-lactamases (Fluit et al., 2001). Watts and Salmon (1997) tested S. aureus isolates from bovine mastitis cases and determined that penicillin and ampicillin were the antimicrobial agents most affected by $\beta$-lactamase activity. In this study, $\beta$-lactamase production and $\beta$-lactam resistance was correlated in the majority of the strains. Only 16 of the $\beta$-lactam-resistant strains were found to be negative in the $\beta$-lactamase test. It should be noted that in this study, the induction of enzyme by testing the growth from the zone margin of oxacillin or penicillin disc was not carried out and this may have some effect on the results. All S. aureus strains were susceptible to amoxicillin-clavulanate, a $\beta$-lactamase inhibitor combination, in this study. Thus, the results indicate that the majority of antimicrobial resistance in $S$. aureus isolates is due to production of $\beta$ lactamases. De Oliveira et al. (2000) also reported that the specific $\beta$-lactam combinations of penicillin-clavulanate and penicillin-novobiocin were very active against $S$. aureus strains. All of the $S$. aureus strains tested in this study were found susceptible to oxacillin. Results of the others studies also indicate that methicillin resistance, which is important for human isolates, is not a problem in bovine isolates (De Oliveira et al., 2000; Gentilini et al., 2000; Calvinho et al., 2002; Erskine et al., 2004)

Overuse and misuse of antibacterial agents have been incriminated as the major selective forces encouraging the development of resistance in bacteria (WHO, 2002). The high rate of resistance against $\beta$-lactam antibiotics and oxytetracycline may be the consequences of the common and uncontrolled use of these groups of antimicrobials in Turkey. Evidently, these are the most widely used 
antimicrobial agents for treating mastitis or other diseases. It should also be considered that milk samples are usually submitted to our laboratory when a prior antimicrobial administration is unsuccessful. This may have an additional effect on the results of this study.

It seems that antimicrobial resistance profile may not be homogeneous in a herd. Among the $27 \mathrm{~S}$. aureus isolates belonging to one herd, different antimicrobial resistance patterns were observed. Therefore, one or several isolates from a herd may not represent the resistance patterns of the isolates from other animals in a given herd.

In this study, $125 \mathrm{~S}$. aureus strains were subtyped by coa gene PCR. Studies (Annemüller et al., 1999; Lange et al., 1999; Raimundo et al., 1999; Schlegelova et al., 2003) carried out in different countries, using the same primer pairs of COA2 and COA3, showed that several coagulase gene types are responsible for the majority of bovine mastitis cases and that some of these coa gene PCR types are predominant in each location. In the present study, a 1000-bp PCR product was the predominant type, accounting for $60.8 \%$ of the isolates typed, whereas only $16.8,12.8$, and $9.6 \%$ of the isolates yielded $900-$, 800-, and 700-bp products, respectively. Similarly, Raimundo et al. (1999) typed $151 \mathrm{~S}$. aureus from 7 farms in Australia and distinguished 6 PCR types with 73.3 and $15.2 \%$ of isolates assigned to $1000-$ and 700 - to $750-$ bp products, respectively. Annemüller et al. (1999) also tested 25 isolates from 6 farms and obtained 4 PCR products of $990,900,800$, and $740 \mathrm{bp}$, with $990 \mathrm{bp}$ being the predominant product. Lange et al. (1999) tested 66 $S$. aureus isolates from different herds and distinguished $7 \mathrm{PCR}$ products that ranged from 580 to $1060 \mathrm{bp}$. Nagase et al. (2002) typed 53 bovine $S$. aureus strains from different regions in Japan and differentiated 6 coagulase types with the most predominant genotype accounting for $77.4 \%$ of the total strains. Schlegelova et al. (2003) identified 3 coagulase genotypes among the 24 milk isolates in a farm, and one genotype (730 bp) was predominant in $83.3 \%$ of the isolates. Su et al. (1999) reported that predominant types of $S$. aureus might be varied in different geographical areas or herds, and that predominant genotypes were more resistant to neutrophil bactericidal activities than rare genotypes.

Other studies on the molecular epidemiological analysis of bovine $S$. aureus isolates using different techniques also suggested that one or a few types of $S$. aureus usually predominate in one herd or area ( Kapur et al., 1995; Lipman et al., 1996; Fitzgerald et al., 1997, 2000; Myllys et al., 1997; Zadoks et al., 2002; Sabour et al., 2004).

\section{CONCLUSIONS}

The results demonstrate that, as in many studies using either MIC values or disc diffusion results conducted in different countries, $S$. aureus isolates are most commonly resistant to penicillin. However, resistance against penicillin was relatively high among the $S$. aureus isolates from bovine mastitis cases tested in this study. The second-highest resistance was observed against oxytetracycline, and little or no resistance was seen with the other antimicrobial agents tested. The findings suggest the requirement of proper use of $\beta$ lactam antibiotics for mastitis therapy. To prevent the unnecessary use of $\beta$-lactams and to achieve effective therapy, isolation of the microorganism and determination of antimicrobial susceptibility is essential. The PCR method based on coagulase gene typing is capable of classifying all $S$. aureus strains and is a relatively uncomplicated, convenient method for typing a large number of strains; however, discriminative capability of this technique may not be adequate.

\section{ACKNOWLEDGMENTS}

The authors wish to thank biologist E. Torlak and laboratory technicians Y. Gür and S. Dursun for their assistance.

\section{REFERENCES}

Aarestrup, F. M., C. A. Dangler, and L. M. Sordillo. 1995a. Prevalence of coagulase gene polymorphism in Staphylococcus aureus isolates causing bovine mastitis. Can. J. Vet. Res. 59:124-128.

Aarestrup, F. M., H. C. Wegener, and V. T. Rosdahl. 1995b. Evaluation of phenotypic and genotypic methods for epidemiological typing of Staphylococcus aureus isolates from bovine mastitis in Denmark. Vet. Microbiol. 45:139-150.

Akan, M., L. Kökçü, T. Öncel, and H. S. Eken. 2001. Mastitislerden izole edilen staphylococ suslarinin beta laktamaz aktivitesi ve bazi antibiyotiklere duyarliliklar. Vet. Hek. Mikrobiyol. Derg. 1:36-41.

Annemüller, C., Ch. Lammler, and M. Zschöck. 1999. Genotyping of Staphylococcus aureus isolated from bovine mastitis. Vet. Microbiol. 69:217-224.

Calvinho, L. F., F. G. Toselli, W. R. Weimann, V. R. Canavesio, V. E. Neder, and I. A. Iguzquiza. 2002. Antimicrobial sensitivity of coagulase-positive staphylococcal strains isolated from bovine mastitis in the central dairy catchment area of Argentina. Rev. Argent. Microbiol. 34:171-175.

De Oliveira, A. P., J. L. Watts, S. A. Salmon, and F. M. Aarestrup, 2000. Antimicrobial susceptibility of Staphylococcus aureus isolated from bovine mastitis in Europe and the United States. J. Dairy Sci. 83:855-862.

Devriese, L. A., F. Haesebrouck, J. Hommez, and R. Vandermeersch. 1997. A 25-year survey of antibiotic susceptibility testing in Staphylococcus aureus from bovine mastitis in Belgium, with special reference to penicillinase. Vlaams Diergeneeskundig Tijdschrift. 66:170-173.

Erskine, R. J., J. Cullor, M. Schaellibaum, B. Yancey, and A. Zecconi. 2004. Bovine mastitis pathogens and trends in resistance to antibacterial drugs. Pages 400-403 in Proc. NMC 43rd Annu. Mtg., Charlotte, North Carolina. National Mastitis Council, Madison, WI.

Erskine, R. J., R. D. Walker, C. A. Bolin, P. C. Barlett, and D. G. White. 2002. Trends in antibacterial susceptibility of mastitis pathogens during a seven-year period. J. Dairy Sci. 85:1111-1118.

Fitzgerald, J. R., P. J. Hartigan, W. J. Meaney, and C. J. Smyth. 2000. Molecular population and virulence factor analysis of Staphylococ- 
cus aureus from bovine intramammary infection. J. Appl. Microbiol. 88:1028-1037.

Fitzgerald, J. R., W. J. Meaney, P. J. Hartigan, C. J. Smyth, and V. Kapur. 1997. Fine-structure molecular epidemiologycal analysis of Staphylococcus aureus recovered from cows. Epidemiol. Infect. 119:261-269.

Fluit, A. C., M. R. Visser, and F.-J. Schmitz. 2001. Molecular detection of antimicrobial resistance. Clin. Microbiol. Rev. 14:836-871.

Gentilini, E., G. Denamiel, P. Llorente, S. Godaly, M. Rebuelto, and O. DeGregorio. 2000. Antimicrobial susceptibility of Staphylococcus aureus isolated from bovine mastitis in Argentina. J. Dairy Sci. 83:1224-1227.

Gianneechini, R. E., C. Concha, and A. Franklin. 2002. Antimicrobial susceptibility of udder pathogens isolated from dairy herds in the west littoral region of Uruguay. Acta Vet. Scand. 43:31-41.

Goh, S. H., S. K. Byrne, J. L. Zhang, and A. W. Chow. 1992. Molecular typing of Staphylococcus aureus on the basis of coagulase gene polymorphisms. J. Clin. Microbiol. 30:1642-1645.

Hadimli, H. H., M. Ates, L. Güler, K. Kav, and T. Öncel. 2001. Mastitisli süt ineklerinden izole edilen stafilokoklarin $\beta$-laktamaz aktiviteleri ve antibiyotiklere duyarliliklari. Vet. Bil. Derg. 17:21-25.

Hesselbarth, J., and S. Schwarz. 1995. Comparative ribotyping of Staphylococcus intermedius from dogs, pigeons, horses and mink. Vet. Microbiol. 45:11-17.

Hookey, J. V., J. F. Richardson, and B. D. Cookson. 1998. Molecular typing of Staphylococcus aureus based on PCR restriction fragment length polymorphism and DNA sequence analysis of the coagulase gene. J. Clin. Microbiol. 36:1083-1089.

Kapur, V., W. M. Sischo, R. S. Greer, T. S. Whittam, and J. M. Musser. 1995. Molecular population genetic analysis of Staphylococcus aureus recovered from cows. J. Clin. Microbiol. 33:376-380.

Lange, C., M. Cardoso, D. Senczek, and S. Schwarz. 1999. Molecular subtyping of Staphylococcus aureus isolates from cases of bovine mastitis in Brazil. Vet. Microbiol. 67:127-141.

Leslie, K. E., Y. H. Schukken, M. Archambault, R. T. Dingwell, A. Bashiri, and C. F. Leslie. 2003. Antimicrobial resistance patterns of Staphylococcus aureus isolated from intramammary infections before and after the dry period of dairy cattle in Canada. Pages 324325 in Proc. NMC 42nd Annu. Mtg., Forth Worth, TX. National Mastitis Council, Madison, WI.

Lipman, L. J. A., A. de Nijs, T. J. G. M. Lam, J. A. Rost, L. van Dijk, Y. H. Schukken, and W. Gaastra. 1996. Genotyping by PCR, of Staphylococcus aureus strains, isolated from mammary glands of cows. Vet. Microbiol. 48:51-55.

Macovec, J. A., and P. L. Ruegg. 2003. Antimicrobial resistance of bacteria isolated from dairy cow milk samples submitted for bacterial culture: 8905 samples (1994-2001). JAVMA 222:1582-1589.

Myllys, V., K. Asplund, E. Brofeldt, V. Hirvela-Koski, T. HonkanenBuzalski, J. Junttila, L. Kulkas, O. Myllykangas, M. Niskanen, H. Saloniemi, M. Sandholm, and T. Saranpaa. 1998. Bovine mastitis in Finland in 1988 and 1995-Changes in prevalence and antimicrobial resistance. Acta Vet. Scand. 39:119-126.

Myllys, V., R. Jouko, J. Björkroth, I. Biese, and S. Pyörälä. 1997. Persistence in bovine mastitis of Staphylococcus aureus clones as assessed by random amplified polymorphic DNA analysis, ribotyping and biotyping. Vet. Microbiol. 51:254-251.

Nagase, N., A. Shimizu, J. Kawano, K. Yamashita, H. Yoshimura, M. Ishimaru, and A. Kojima. 2002. Characterisation of Staphylococcus aureus strains isolated from bovine mastitis in Japan. J. Vet. Med. Sci. 64:1169-1172.

National Committee for Clinical Laboratory Standards. 2002. Performance standards for antimicrobial disk and dilution susceptibility tests for bacteria isolated from animals; approved standard. 2nd ed. NCCLS document M31-A2. Natl. Committee for Clinical Laboratory Standards, Wayne, PA.

Pengov, A., and S. Ceru. 2003. Antimicrobial drug susceptibility of Staphylococcus aureus strains isolated from bovine and ovine mammary glands. J. Dairy Sci. 86:3157-3163.

Pitkala, A., M. Haveri, S. Pyorala, V. Myllys, and T. Honkanen-Buzalski. 2004. Bovine mastitis in Finland 2001-Prevalence, distribution of bacteria, and antimicrobial resistance. J. Dairy Sci. 87:2433-2441.

Quinn, P. J., M. E. Carter, B. K. Markey, and G. R. Carter. 1998. Clinical Veterinary Microbiology. 2nd ed. Mosby, London, UK.

Raimundo, O., M. Deighton, J. Capstick, and N. Gerraty. 1999. Molecular typing of Staphylococcus aureus of bovine origin by polymorphisms of the coagulase gene. Vet. Microbiol. 66:275-284.

Sabour, P. M., J. J. Gill, D. Lepp, J. C. Pacan, R. Ahmed, R. Dingwell, and K. Leslie. 2004. Molecular typing and distribution of Staphylococcus aureus isolates in Eastern Canadian dairy herds. J. Clin. Microbiol. 42:3449-3455.

Salmon, S. A. 2002. Use of antimicrobial susceptibility data to assist in determining the best therapy for clinical mastitis. Page 36 in Proc. NMC 41st Annu. Mtg., Orlando, FL. National Mastitis Council, Madison, WI.

Schlegelova, J., M. Dendis, J. Benedik, V. Babak, and D. Ryşanek. 2003. Staphylococcus aureus isolates from dairy cows and humans on a farm differ in coagulase genotype. Vet. Microbiol. 92:327-334.

Su, C., C. Herbelin, N. Frieze, O. Skardova, and L. M. Sordillo. 1999. Coagulase gene polymorphism of Staphylococcus aureus isolates from dairy cattle in different geographical areas. Epidemiol. Infect. 122:329-336.

Schwarzkopf, A., and H. Karch. 1994. Genetic variation in Staphylococcus aureus coagulase genes: Potential and limits for use as epidemiological marker. J. Clin. Microbiol. 32:2407-2412.

Tenover, F. C., R. Arbeit, G. Archer, J. Biddle, S. Byrne, R. Goering, G. Hancock, G. A. Hébert, B. Hill, R. Hollis, W. R. Jarvis, B. Kreiswirth, W. Eisner, J. Maslow, L. K. McDougal, M. Miller, M. Mulligan, and M. A. Pfaller. 1994. Comparison of traditional and molecular methods of typing isolates of Staphylococcus aureus. J. Clin. Microbiol. 32:407-415.

Türütoğlu, H., Ş. Mudul, and F. Pehlivanoğlu. 2002. Antibiotic susceptibility and $\beta$-lactamase prevalence for Staphylococci isolated from bovine mastitic milk samples. Acta Vet. 52:337-344.

Vecht, U., H. J. Wisselink, and H. M. Vette. 1989. Sensitivity pattern of Staphylococcus aureus isolated from quarter milk from cattle. Tijdschr Diergeneeskd. 114:260-269.

Vintov, J., F. M. Aarestrup, C. E. Zinn, and J. E. Olsen. 2003. Association between phage types and antimicrobial resistance among bovine Staphylococcus aureus from 10 countries. Vet. Microbiol. 95:133-147.

Watts, J. L., and S. A. Salmon. 1997. Activity of selected antimicrobial agents against strains of Staphylococcus aureus isolated from bovine intramammary infections that produce beta-lactamase. J. Dairy Sci. 80:788-791.

WHO. 2002. Antimicrobial resistance. WHO Media Center. Available: http://www.who.int/mediacenter/factsheets/fs194. Accessed Jan. 2004.

Yoshimura, H., M. Ishimaru, and A. Kojima. 2002. Minimum inhibitory concentrations of 20 antimicrobial agents against Staphylococcus aureus isolated from bovine intramammary infections in Japan. J. Vet. Med. B. 49:457-460.

Zadoks, R. N., W. B. van Leeuwen, D. Kreft, L. K. Fox, H. W. Barkema, Y. H. Schukken, and A. van Belkum. 2002. Comparison of Staphylococcus aureus isolates from bovine and human skin, milking equipment, and bovine milk by phage typing, pulsed-field gel electrophoresis, and binary typing. J. Clin. Microbiol. 40:3894-3902. 